\title{
WASTE TO ENERGY: INVESTIGATION, TECHNOLOGIES AND EVALUATION SYSTEM
}

\author{
Zhou Gongming \\ Chen Dezhen \\ Zhai Xulu \\ Tongji University, China
}

\begin{abstract}
Supported by the on going project on "Sustainable Solid Waste Landfill Management in Asia" under the Asian Regional Research Programme on Environmental Technology funded by Swedish International Development Cooperation Agency and Coordinated by Asian Institute of Technology, Thailand, a combined waste-to-energy (WTE) process has been developed in China. In this research two fresh and five aged municipal solid wastes (MSW) samples were investigated and characterized. Based on the analysis of results, suggestions were proposed for the proper WTE system with aged MSW from dumpsites and landfills and fresh MSW considered together. The WTE process included hierarchy of recycling plastics from fresh MSW as raw material and recycling combustibles from aged MSW as RDF. To recycle the plastics from fresh MSW, separation and purification system have been set up and their energy consumption was counted.
\end{abstract}

Two analysis tools including life cycle assessment (LCA) and cost benefit analysis (CBA) have been adopted for the WTE system evaluation. Based on the necessary data collected during investigation process, LCA was carried out for RDF production from aged MSW and utilization in fresh MSW incinerator; and CBA was performed for plastics recycling from fresh MSW; good results have been obtained from those evaluations suggested the proposed WTE processes are promising.

\section{KEYWORDS}

Waste-to-energy (WTE) process; Municipal solid wastes; Refused derived fuel; Life cycle assessment; Cost benefit analysis.

\section{INTRODUCTION}

Waste to energy (WTE) is a common and essential method to dispose municipal solid wastes (MSW). But considering the characteristics of wastes are different from country to country and from region to region, there is non-universal method for effective and economical WTE process. Incineration is a good method for disposal of non-recoverable wastes, in some developed countries such as Denmark and Germany, MSW incineration is an important source of compensatory energy to replace the common fuels' consumption. But in most developing countries, incineration is difficult to popularize due to the expensive investment as well as the low level of lower heat value (LHV). In addition to incineration, gasification and pyrolysis are also important thermal processes involved in WTE process. But apparatuses 
only running on gasification and pyrolysis mechanism are very rare in developing countries, either in most developed countries. Biogas production from anaerobic processes is another alternative to WTE, but this is only applicable to degradable organics like garden and food wastes. In China MSW are not sorted at collection, and for long time landfill and dumpsite are the places for MSW storage. Proper WTE process may be chosen only after basic data of those newly generated and stored MSW are available. In this paper, an investigation was performed first and then WTE processes were suggested with proper evaluation tools to judge their feasibilities.

\section{INVESTIGATION OF MSW}

Two fresh MSW samples and five aged MSW were sampled and investigated. The investigation method included sampling, separation, weighing and drying, etc. Composition data for those MSW were listed (see Tables 1, 2 and 3):

Table 1. Components of fresh MSW in Shanghai (from Feb. 2004 - Jun. 2004) (\%wt).

\begin{tabular}{|c|c|c|c|c|c|c|c|c|c|}
\hline \multirow{2}{*}{$\begin{array}{c}\text { Sampling } \\
\text { month }\end{array}$} & \multirow{2}{*}{ Paper } & \multirow{2}{*}{$\begin{array}{c}\text { Plastics/ } \\
\text { rubber }\end{array}$} & \multirow{2}{*}{$\begin{array}{l}\text { Wood \& } \\
\text { bamboo }\end{array}$} & \multirow{2}{*}{ Fabric } & \multicolumn{3}{|c|}{ Kitchen wastes } & \multirow{2}{*}{$\begin{array}{l}\text { Metals } \\
\text { \& glass }\end{array}$} & \multirow{2}{*}{$\begin{array}{l}\text { Slag \& } \\
\text { sinters }\end{array}$} \\
\hline & & & & & Plant & Animal & Residue & & \\
\hline \multirow[t]{2}{*}{ Feb. } & 12.83 & 17.71 & 5.65 & 5.45 & 22.65 & 6.68 & 23.71 & 1.52 & 3.8 \\
\hline & 61.14 & 35.04 & 61.41 & 47.81 & 54.96 & 40.7 & 50.84 & & \\
\hline \multirow[t]{2}{*}{ Mar. } & 17.08 & 20.57 & 5.65 & 4.98 & 25.11 & 8.2 & 14.86 & 1.84 & 1.68 \\
\hline & 62.84 & 40.26 & 55.85 & 41.87 & 57.78 & 46.1 & 51.59 & & \\
\hline \multirow[t]{2}{*}{ Apr. } & 13.4 & 17.68 & 6.45 & 5.89 & 20.75 & 4.76 & 23.28 & 4.02 & 3.77 \\
\hline & 57.18 & 40.53 & 54.07 & 45.28 & 64.39 & 44.7 & 45.69 & & \\
\hline \multirow[t]{2}{*}{ May. } & 17.72 & 21.4 & 11.15 & 5.34 & 22.49 & 5.62 & 12.11 & 3.44 & 0.73 \\
\hline & 52.91 & 41.3 & 66.01 & 49.13 & 77.29 & 45.8 & 48.65 & & \\
\hline \multirow[t]{2}{*}{ Jun. } & 16.81 & 20.07 & 10.14 & 6.61 & 26.1 & 6.21 & 10.55 & 2.79 & 0.72 \\
\hline & 62.09 & 48.01 & 49.03 & 53.37 & 71.41 & 43.9 & 57.72 & & \\
\hline
\end{tabular}

${ }^{\prime}$ C-mass content; ${ }^{2}$ M-moisture content in this component

When analyzing the composition of the MSW, the system shown (see Figure l) was adopted. The system including sampling operation for aged wastes was not only used to analyze the sample composition, but also used for economic data investigation. 
Table 2. Components of fresh MSW in Changshu (from Jul. 2003-Dec. 2003) (\%wt).

\begin{tabular}{|c|c|c|c|c|c|c|c|c|c|c|}
\hline \multirow{2}{*}{$\begin{array}{l}\text { Sampling } \\
\text { month }\end{array}$} & \multirow{2}{*}{ Paper } & \multirow{2}{*}{$\begin{array}{l}\text { Plastics/ } \\
\text { rubber }\end{array}$} & \multirow{2}{*}{$\begin{array}{l}\text { Wood \& } \\
\text { bamboo }\end{array}$} & \multirow{2}{*}{ Fabric } & \multicolumn{3}{|c|}{ Kitchen wastes } & \multirow{2}{*}{-Metals } & \multirow{2}{*}{$\begin{array}{l}\text { Glass \& } \\
\text { ceramics }\end{array}$} & \multirow{2}{*}{$\begin{array}{l}\text { Slag \& } \\
\text { sinters }\end{array}$} \\
\hline & & & & & Plant & Animal & Residue & & & \\
\hline \multirow[t]{2}{*}{ Jul. } & 7.53 & 14.90 & 10.06 & 8.51 & 46.473 & 3.62 & 4.61 & 0.37 & 1.86 & 2.067 \\
\hline & 65.57 & 67.76 & 56.09 & 69 & 83.57 & 52.28 & 78.90 & 8.1 & 28.18 & 32.4 \\
\hline \multirow[t]{2}{*}{$\overline{\text { Aug. }}$} & 11.49 & 14.03 & 7.07 & 9.12 & 36.82 & 3.07 & 9.25 & 0.67 & 2.53 & 5.95 \\
\hline & 51.52 & 44.99 & 68.19 & 44.2 & 83.63 & 51.29 & 59.67 & 9.59 & 4.57 & 20.51 \\
\hline \multirow[t]{2}{*}{ Sept. } & 11.40 & 20.17 & 10.87 & 5.85 & 33.48 & 5.08 & 8.41 & 0.78 & 1.84 & 2.18 \\
\hline & 48.87 & 43.08 & 60.34 & 36.67 & 72.98 & 57.4 & 79.70 & 8.0 & 6.00 & 15.31 \\
\hline \multirow[t]{2}{*}{ Oct. } & 7.06 & 14.53 & 7.3 & 6.78 & 35.22 & 6.88 & 17.79 & 0.34 & 3.29 & 1.28 \\
\hline & 55.97 & 53.17 & 48.08 & 41.95 & 78.51 & 53.48 & 52.04 & 1.0 & 16.19 & 22.74 \\
\hline \multirow[t]{2}{*}{ Nov. } & 11.34 & 13.00 & 5.54 & 7.4 & 30.08 & 6.24 & 19.58 & 0.6 & 2.39 & 3.58 \\
\hline & 49.35 & 49.69 & 52.93 & 41.92 & 79.74 & 52.52 & 55.06 & 1.0 & 2.3 & 27.80 \\
\hline \multirow[t]{2}{*}{$\overline{\text { Dec. }}$} & 13.71 & 18.16 & 3.95 & 5.79 & 23.88 & 5.96 & 14.63 & 0.56 & 8.77 & 4.6 \\
\hline & 44.06 & 56.63 & 62.07 & 35.69 & 79.05 & 52.72 & 48.04 & 0 & 2.10 & 17.91 \\
\hline
\end{tabular}

Table 3. Components of aged MSW in Shanghai from landfill site and from dumpsite (\%wt).

\begin{tabular}{llllllllll}
\hline Samples & \multicolumn{3}{c}{ Plastics Rubber } & $\begin{array}{l}\text { Wood } \\
\text { \& grass }\end{array}$ & Fabrics & Paper & $\begin{array}{l}\text { Stone/ } \\
\text { glass/tile }\end{array}$ & Soil & $\begin{array}{l}\text { LHV of } \\
\text { combustibles }\end{array}$ \\
\hline Dumping & C & 7.33 & 0.44 & 0.45 & 2.42 & 0.13 & 6.23 & 81.36 & 18141 \\
site & M & 26.95 & 25.57 & 40.23 & 37.08 & 30.12 & & & \\
10 years & C & 7.02 & 0.82 & 2.47 & 1.16 & 0 & 12.08 & 75.48 & 18176 \\
landfill & M & 27.6 & 15.12 & 23.85 & 27.7 &.- & & & 17451 \\
7 years & C & 22.18 & 1.0 & 3.87 & 4.15 & 0.47 & 18.2 & 50.13 & 14451 \\
landfill & M & 39.86 & 24.77 & 52.53 & 49.18 & 59.22 & & & \\
5 years & C & 26.71 & 0.23 & 6.09 & 8.97 & 1.82 & 10.24 & 45.94 & 11620 \\
landfill & M & 49.4 & 21.57 & 44.76 & 48.15 & 60.51 & & & \\
3 years & C & 23.12 & 0.58 & 3.89 & 5.49 & 0.95 & 13.86 & 52.1 & 13676 \\
landfill & M & 45.2 & 11.85 & 40.06 & 35.76 & 65.09 & & & \\
\hline
\end{tabular}

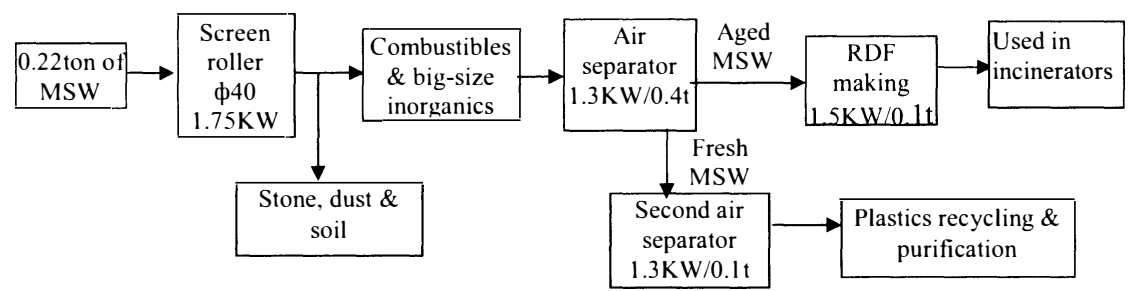

Figure 1. Separation system for aged and fresh MSW for analysis and energy data collection. 


\section{WTE PROCESS}

\subsection{WTE process for fresh MSW}

The common WTE process for fresh MSW is incineration accompanied with power generation or heating supply. But as the main energy from MSW comes from plastics (see Figure 2), it may be more energy effective to recycle those plastics than to incinerate them due to fossil $\mathrm{CO}_{2}$ emission and dioxins formation involved in their incineration process [1].

An investigation of plastics contained in fresh wastes is shown (see Table 4):

Table 4. Species of plastics contented in total plastics in fresh MSW (\%w') (samples in Shanghai).

\begin{tabular}{lllllll}
\hline $\begin{array}{l}\text { Plastics } \\
\text { specifics }\end{array}$ & $\begin{array}{l}\text { Juice \& milk } \\
\text { package; } \\
\text { aluminium, plastics }\end{array}$ & $\begin{array}{l}\text { Soft } \\
\text { plastics } \\
\text { (PE \& PP) }\end{array}$ & $\begin{array}{l}\text { Plastics } \\
\text { bottles } \\
(\text { PET) }\end{array}$ & $\begin{array}{l}\text { Plastics } \\
\text { bottles } \\
(\text { PP) }\end{array}$ & $\begin{array}{l}\text { Hard } \\
\text { plastics } \\
(\text { PP) }\end{array}$ & $\begin{array}{l}\text { Other } \\
\text { plastics }\end{array}$ \\
\hline Content & 13.2 & 75.9 & 0.61 & 0.93 & 1.36 & 8.0 \\
\hline
\end{tabular}

From Table 4 it can be seen that most of the plastics in the fresh MSW are soft PE \& PP plastic film; plastics bottles of PET material are the main objective for informal recycling, so its content is low. In juice \& milk package plastics is filmed together with paper and aluminum, this kind of plastics is hard to be recycled. The part that can be easily recycled in the separation system showed in Figure $l$ is the soft plastics. And their recycling rate is around $80 \%$ [2]. If the plastics content in fresh MSW is around $22 \%$ by dry basis (see Table $1)$, then the recycled PE \& PP plastics is around $135 \mathrm{~kg} / \mathrm{t}$ of dry MSW. The purity PE \& PP material is around $60 \%$ according to investigation data [2]; so $81 \mathrm{~kg}$ PE \& PP plastics can be recycled from per ton of dry MSW or $38.88 \mathrm{~kg} / \mathrm{t}$ of wet MSW for secondary plastics products.

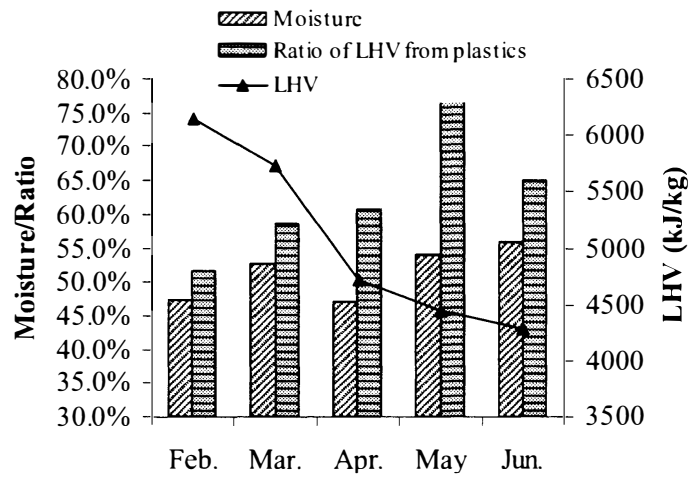

Figure 2. Overall moisture content, $L H V$ and ratio of $L H V$ from plastics in fresh $M S W$ 
samples from Shanghai changing with month (sampled in 2004).

\subsection{WTE process for aged MSW}

Although the plastics in the aged MSW are easier to be separated in system shown in Figure 1 than those in fresh MSW, the quality is not good enough to be recycled [3]. And to recycle all of the combustibles including plastics to produce RDF is the better choice for carrying out WTE process [4].

RDF process included separation of combustibles, producing RDF with additives and RDF transportation and combustion in fresh MSW incineration plants (see Figure 1). When fresh and aged MSW treatment consider together, the comprehensive WTE process can be shown in Figure 3. Compared to other WTE process, application of system in Figure 3 has the impacts of:

- High level of energy recovery from fresh and aged MSW, and volume reduction of aged MSW;

- Improve the combustion conditions of fresh MSW and prevent the emission of toxic organics; and

- Reduction of auxiliary fuel in fresh MSW incinerator. 


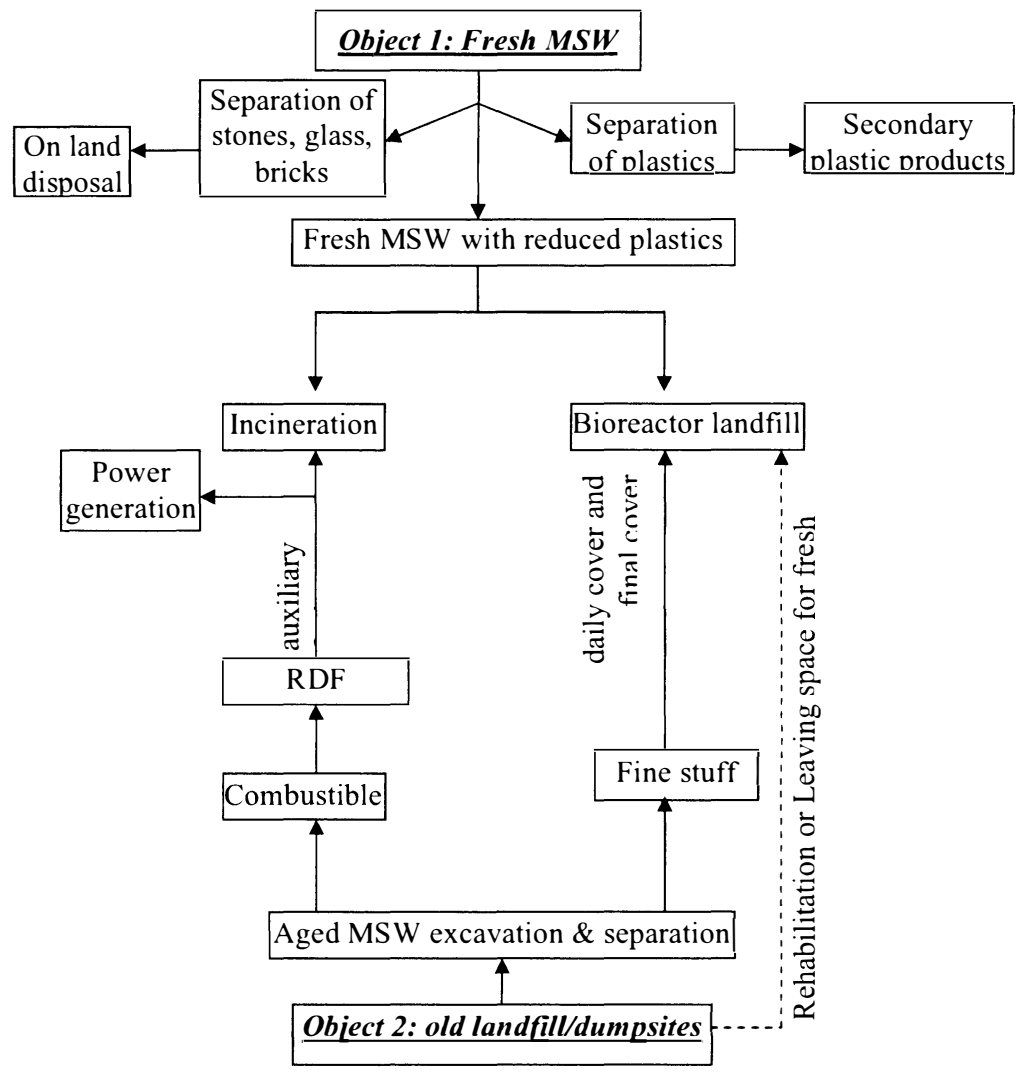

Figure 3. Overall WTE process for fresh and aged MSW.

\section{SYSTEM EVALUATIONS}

There should be some evaluation tools to judge whether the WTE process is beneficial environmentally and economically, two useful tools that can be adopted for this purpose are life cycle assessment (LCA) and cost benefit analysis (CBA). LCA is a holistic approach that takes account every necessary factor from "cradle to grave". When used to evaluate WTE process it covers all main activities related to the energy recovering system at the same time and translates the information into resource consumptions and potential environmental impacts. In CBA method the planned project and the baseline scenario are compared when the project costs including the cost of investment and operation, the project income including direct and indirect income are considered. If the net present value (NPV) is positive, then the project is acceptable from economy. However, to carry out those LCA and CBA evaluations, the basic database should be built up. And LCA and CBA evaluations can be applied to the overall process as well as the singles steps with view to optimize the step. In this study we have collected the necessary data based on characterizing investigation process and pilot 
WTE system, LCA process will apply to RDF from 10 years' old MSW and incinerated in a fresh MSW incinerator fuelled with fresh MSW in Shanghai; while CBA was used to analyze the plastics recycling from fresh MSW.

\subsection{Life cycle assessment of RDF process from aged wastes}

Here LCA analysis is carried out to evaluate RDF utilization system with help of the newly developed program EASEWASTE (Environmental Assessment of Solid Waste Systems and Technologies). Framework and structure of EASEWASTE was described in detail by [5]. Table 5 presents the important categories related to waste management technology and the normalization reference used to convert the individual potential impact categories into person equivalents (PE), which is an average value for the yearly contribution to that impact category by all the activities and consumptions of one person in Europe and can be replaced by those data from the country or the region being considered.

Table 5. Potential impact categories included in EASEWASTE.

\begin{tabular}{|c|c|c|c|c|}
\hline $\begin{array}{c}\text { Potential impact } \\
\text { category }\end{array}$ & Acronym & Unit & $\begin{array}{c}\text { Physical } \\
\text { basis }\end{array}$ & $\begin{array}{c}\text { Normalization } \\
\text { reference EDIP97 }\end{array}$ \\
\hline $\begin{array}{c}\text { Global warming, } \\
100 \text { years }\end{array}$ & GW 100 & $\mathrm{~kg} \mathrm{CO}_{2}$-eq. /person/yr & Global & 8700 \\
\hline Acidification & $\mathrm{AC}$ & $\mathrm{kg} \mathrm{SO}_{2}$-eq. /person/yr & Regional & 74 \\
\hline Nutrient enrichment & $\mathrm{NE}$ & $\mathrm{kg} \mathrm{NO}_{3}^{-}$-eq. / person/yr & Regional & 119 \\
\hline Human toxicity, soil & HTs & $\mathrm{m}^{3}$ soil $/$ person $/ \mathrm{yr}$ & Regional & 157 \\
\hline $\begin{array}{c}\text { Human Toxicity, } \\
\text { water }\end{array}$ & HTw & $\mathrm{m}^{3}$ water $/$ person $/ \mathrm{yr}$ & Regional & 179000 \\
\hline $\begin{array}{l}\text { Ecotoxicity, } \\
\text { water chronic }\end{array}$ & ETwc & $\mathrm{m}^{3}$ water $/$ person $/ \mathrm{yr}$ & Regional & 352000 \\
\hline Bulky waste & BW & $\mathrm{kg} /$ person/yr & Regional & 1350 \\
\hline Hazardous & HW & $\mathrm{kg} /$ person$/ \mathrm{yr}$ & Regional & 20.7 \\
\hline Slag \& ash & SA & $\mathrm{kg} /$ person $/ \mathrm{yr}$ & Regional & 350 \\
\hline $\begin{array}{c}\text { Photochemical ozone } \\
\text { formation, low and } \\
\text { high NOx }\end{array}$ & $\begin{array}{l}\mathrm{PhOI}, \\
\mathrm{PhOH}\end{array}$ & $\mathrm{kg} \mathrm{C}_{2} \mathrm{H}_{4}$-eq/person/yr & Regional & 25 \\
\hline
\end{tabular}


Figure 4 gives the calculated potential impacts of different categories connected with RDF production, RDF incineration in person equivalents (PE). The positive value in PE means the harmful impacts to the environment; while negative values mean saving the environmental impacts. It can be seen that RDF production process causes harmful impacts to environment due to energy and material Consumption, especially for category of human toxicity via soil (HTs). But due to the power generated from RDF utilization systems, their potential impacts to the environment are generally negative if transportation considered. To keep negative PE data, RDF transportation should be less than $29.2 \mathrm{~km}$ [4], this can be easily controlled if used in the same city.

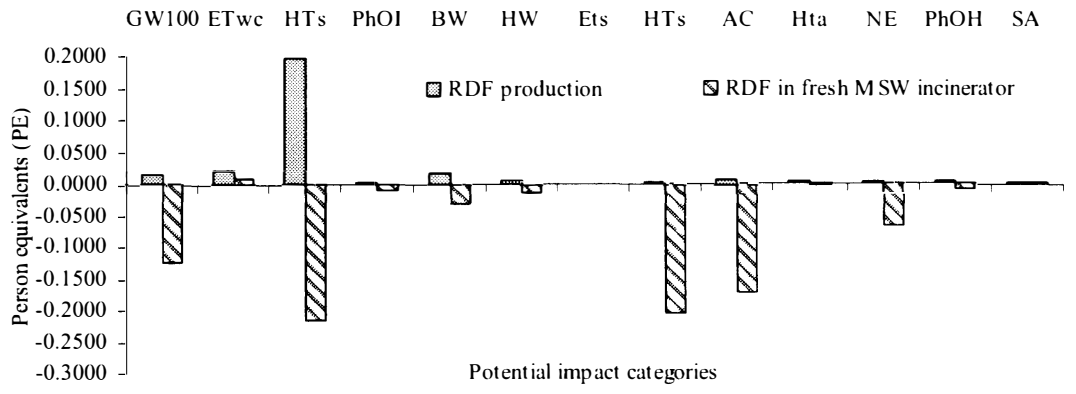

Figure 4. Tonnage environmental impact potentials for the RDF utilization system.

\subsection{Cost benefits analysis of plastics recycling from fresh MSW}

In the planned project, the plastics were separated from fresh MSW by the mechanical separation plant shown (see Figure l) sited in incineration plant with an input capacity of 40 tons MSW/h. The sifter efficiency for PE \& PP plastics is $38.88 \mathrm{~kg} / \mathrm{t}$ of fresh MSW; the price for this quality plastics is around $280 \mathrm{US} \$ /$ ton. The baseline scenario is without plastics recycling. The impacts of the project include economical and environmental benefits. Economical benefits consist of raw material income. The recycled plastics can be sold to factories for new products production. Environmental benefits consist of pollution prevention, which was a result of better combustion caused by RDF addition instead of direct plastics incineration. For aged MSW they are compulsorily to be excavated due to the need of land space therefore they are not considered in this analysis step.

\subsubsection{Project costs}

The project costs include the cost of the separation plants (separation equipments as well as the pollution control equipments), the imputed value of the land. Table 6 shows the project costs when recycling plastics from fresh MSW incineration plant. 
Table 6. Project costs caused by recycling plastics from MSW (US\$/t).

\begin{tabular}{lccccc}
\hline Item & $\begin{array}{c}\text { Recycling } \\
\text { equipment }\end{array}$ & Land occupy & Labor costs & $\begin{array}{c}\text { Operation } \\
\text { cost }\end{array}$ & Heat loss \\
\hline Unit & US\$/(t.d) & $\mathrm{m}^{2} /(40 \mathrm{t} / \mathrm{h})$ & US\$ $/ \mathrm{t}(40 \mathrm{t} / \mathrm{h})$ & $\mathrm{US} \$ / \mathrm{t}$ & $\mathrm{US} \$ / \mathrm{t}$ \\
Cost data & 12500 & 200 & 0.25 & 0.90 & $6.55^{*}$ \\
\hline
\end{tabular}

*: Power generation reduced due to the recycling of plastics

\subsubsection{Present benefits of the projects}

The economical benefits of the project include 1) the recycled plastics material; 2) the pollutants reduced. Table 7 shows the benefits resulted from plastics in fresh and old MSW respectively. For fresh MSW it is assumed that tonnage recycling rate of plastics is $38.88 \mathrm{~kg}$ plastics of PE \& PP material.

Table 7. Project present benefits (US\$/t fresh MSW).

\begin{tabular}{cccc}
\hline Item & Pollutant reduction & Plastics recovered & Indirect benefit \\
\hline Data & $5.04^{*}$ & $0.88(0.267 \$ / \mathrm{kg})$ & 2.72 \\
\hline
\end{tabular}

*: The operation fee caused by activated carbon consumption which is needed in extra when plastics is incinerated together with other combustibles in MSW.

The indirect benefit (see Table 7) includes environmental benefits such as global warming potential reduction because of recycling plastics as raw material instead of incineration. For per ton of $\mathrm{CO}_{2}$ emission, the cost is US\$ 6.9; and the mass content of mineral carbon in plastics is around $65 \%$; however, when the plastics recycled, auxiliary fuel such as RDF may need, therefore the reduction of $\mathrm{CO}_{2}$ emission will be weakened. Other indirect benefit includes reduced pollution due to crude oil production, where the plastic raw material comes from; and other valuable materials recycled at the same time. Generally the indirect benefit is presumed to be $25 \%$ of the direct benefit.

\subsubsection{Calculation of net present value}

The main index in CBA is net present value (NPV), it is defined as:

$$
N P V=\sum_{i=1}^{T} \frac{B t-C t}{(1+r)^{\prime}}
$$

Where $\mathrm{Bt}$ and $\mathrm{Ct}$ are the benefit and cost at the $\mathrm{t}$-th year. $\mathrm{R}$ is discount rate, and $\mathrm{t}$ is the calculation year. If NPV $>0$, the project is acceptable. If the project lasts for 15 years, and the discount rate is $12 \%$. The yearly cost, benefit and present value of benefits of the projects are shown (see Table 8 ).

From Table 8 it can be seen that investment cost of plastics recovery is the most expensive part of cost; yet NPV of plastics recovery has the positive value from the second year till the last service year. The total positive NPV suggested that the recycle project deserves to set up. 
Table 8. Yearly costs, benefit and NPV of plastics recycling project.

\begin{tabular}{|c|c|c|c|c|c|c|c|}
\hline \multirow[b]{2}{*}{ Year } & \multirow{2}{*}{$\begin{array}{l}\text { Recycle } \\
\text { capacity } \\
\text { (ton) }\end{array}$} & \multicolumn{3}{|c|}{$\operatorname{Costa} 10^{3}$ US\$) } & \multicolumn{2}{|c|}{ Benefit ( $10^{3}$ US\$) } & \multirow{2}{*}{$\begin{array}{l}\operatorname{NPV}\left(10^{3} \mathrm{US} \$\right) \\
\text { Discount }(\mathrm{r}=12 \%)\end{array}$} \\
\hline & & $\begin{array}{l}\text { Equipment } \\
\text { \& land }\end{array}$ & Labor & Operation & $\begin{array}{l}\text { Direct } \\
\text { income }\end{array}$ & $\begin{array}{l}\text { Indirect } \\
\text { income }\end{array}$ & \\
\hline 1 & $300 \times 10^{3}$ & 13100 & 75 & 2235 & 4776 & 816 & -9818 \\
\hline 2 & $300 \times 80^{3}$ & 833.33 & 75 & 2235 & 4776 & 816 & 2186.3 \\
\hline 3 & $300 \times 10^{3}$ & 833.33 & 75 & 2235 & 4776 & 816 & 1952 \\
\hline 4 & $300 \times \notin 0^{3}$ & 833.33 & 75 & 2235 & 4776 & 816 & 1743 \\
\hline 5 & $300 \times 10^{3}$ & 833.33 & 75 & 2235 & 4776 & 816 & 1556.2 \\
\hline 6 & $300 \times 10^{3}$ & 833.33 & 75 & 2235 & 4776 & 816 & 1389.4 \\
\hline 7 & $300 \times 80^{3}$ & 833.33 & 75 & 2235 & 4776 & 816 & 1240.6 \\
\hline 8 & $300 \times 10^{3}$ & 833.33 & 75 & 2235 & 4776 & 816 & 1107.6 \\
\hline 9 & $300 \times 10^{3}$ & 833.33 & 75 & 2235 & 4776 & 816 & 989 \\
\hline 10 & $300 \times 40^{3}$ & 833.33 & 75 & 2235 & 4776 & 816 & 883 \\
\hline 11 & $300 \times 40^{3}$ & 833.33 & 75 & 2235 & 4776 & 816 & 788.4 \\
\hline 12 & $300 \times 10^{3}$ & 833.33 & 75 & 2235 & 4776 & 816 & 704 \\
\hline 13 & $300 \times 10^{3}$ & 833.33 & 75 & 2235 & 4776 & 816 & 628.5 \\
\hline 14 & $300 \times 10^{3}$ & 833.33 & 75 & 2235 & 4776 & 816 & 561.2 \\
\hline 15 & $300 \times 10^{3}$ & 833.33 & 75 & 2235 & 4776 & 816 & 501 \\
\hline Total & $4500 \times 10^{3}$ & & & & & & $64 d 2.2$ \\
\hline
\end{tabular}

\section{CONCLUSIONS}

Fresh and aged municipal solid wastes (MSW) were analyzed and characterized with a view for the proper WTE process. Investigation data showed that fresh MSW are characterized with high moisture content and low LHV, while combustibles in aged MSW are mainly plastics and of lower moisture content therefore can be made into refused derived fuel (RDF). The proper WTE process for fresh MSW is to recycle plastics for raw materials while the reduced LHV can be complemented with RDF from aged MSW for a good incineration operation. LCA was performed to judge the above WTE process; the results showed that using RDF as auxiliary fuel in fresh MSW incinerator is beneficial, but the distances of RDF transportation to the incineration plants should be controlled. CBA has been done to evaluate the project of recycling plastics from fresh MSW. Compared to the baseline scenario without plastics recycling, the recycling project corresponds to positive NPV from the second year of the project service till its presumed lifetime, therefore they deserve investment.

Investigation and evaluation results suggested that in China background the WTE process should be arranged for fresh and aged MSW management simultaneously; to recycle plastics from fresh MSW for raw materials and to recycle combustibles from aged MSW for RDF production are not only to be done for purpose of land space saving but also for energy recovery.

\section{ACKNOWLEDGEMENTS}

This project is supported by Asian Regional Research Programme on Environmental Technology "Sustainable Solid Waste Landfill Management in Asia" funded by Swedish 
International Development Cooperation Agency (Sida).

\section{REFERENCES}

[1] Gordon McKay, 2002. Dioxin characterisation, formation and minimisation during municipal solid waste (MSW) incineration: review. Chemical Engineering Journal, 86, 343-368.

[2] Fu, D., 2007. Study on recycling plastics from MSW for Anti-slip board and pipe products. Master thesis: Tongji University, Shanghai.

[3] Zhou., G., Chen, D., Cui, W., 2007.Comparison between fresh and aged municipal solid wastes and their recycling methods in China; in Proceeding of Sardinia 2007, Eleventh International Waste Management and Landfill Symposium, 1-5 Oct., Calgiari, Italy.

[4] Chen, D., Zhai, X., Zhou, G., 2007. Life cycle assessment of RDF production from aged MSW and its utilization system, in Proceedings of the international conference on "Sustainable solid waste management", Sept. 5-7, Chennai, India, 406-414.

[5] Kirkeby, J.T., Bhander, G.S., Birgisdottir, H., Hansen, T.L, Hauschild, M., Christensen, T.H., 2006. Environmental assessment of solid waste systems and technologies: EASEW ASTE. Waste Management \& Research, 24, 3-15. 